\title{
Yield Losses from Delayed Harvest of Paprika Pepper
}

\author{
Brian A. Kahn ${ }^{1}$ \\ Department of Horticulture and Landscape Architecture, Oklahoma State \\ University, Stillwater, OK 74078-0511 \\ Additional index words. Capsicum annum, mechanical harvest
}

\begin{abstract}
Paprika pepper (Capsicum annuum L.) plants were subjected to a single, destructive harvest in either October, November, or December to determine an optimal month for once-over harvest. Studies were conducted at two locations in Oklahoma each year for 2 years. Total and marketable fruit yields were highest with October harvest dates in three of the four experiments. Marketable fruit red pigment intensity decreased between the November and December harvest dates at both locations in the second year. When the crop is established by transplanting, paprika harvest should be completed during October in the southwestern United States.
\end{abstract}

Sweet paprika is a major international spice commodity. The demand for paprika oleoresins has increased due to bans on artificial coloring substances in the United States and other countries (Wolf and Alper, 1984). Domestic buyers are interested in reducing dependence on imports, and some field-crop growers in the southwestern United States are trying paprika as an alternative crop (Kahn, 1985). However, high labor requirements for picking the fruit by hand are a major limitation to expanded production (Wolf and Alper, 1984). A mechanical paprika harvesting system has been developed in Israel, but efficient harvest mechanization also requires establishment of complementary horticultural practices (Wolf and Alper, 1984). Horticultural aspects of mechanized paprika harvesting have not been studied extensively, especially in the United States. Most

Received for publication 9 Sept. 1991. Accepted for publication 18 Mar. 1992. Journal Article no. J-6084 of the Agr. Expt. Sta., Oklahoma State Univ., Stillwater. I express appreciation to Nancy Maness for performing the color intensity analyses. The information given in this publication is for educational purposes only. Mention of a trademark, proprietary product, or vendor does not constitute a guarantee or warranty of the product, nor does it imply approval or disapproval to the exclusion of other products or vendors that may also be suitable. The cost of publishing this paper was defrayed in part by the payment of page charges. Under postal regulations, this paper therefore must be hereby marked advertisement solely to indicate this fact.

'Associate Professor. of the research has focused on the development of ideal plant types (Kahn, 1985; Marshall, 1984).

One important horticultural aspect of mechanized paprika production is the timing of the once-over, destructive harvest. Allowing the fruit to dry naturally on the plant before harvest can lower transport and storage volume and reduce the energy required to artificially dry the fruit in the dehydration plant (Palevitch et al., 1975). However, Israeli studies on timing of paprika harvest were conducted at a location where rainfall was almost totally absent after fruit ripening had begun and where minimum air temperatures remained > 10C (Palevitch et al., 1975). The present study was designed to determine an optimal month for once-over harvest of paprika pepper in the southwestern United States, where both rain and frost must be considered.

Seed of 'KSl' paprika for transplant production was sown in a bulk bench filled with peat-lite mix in a greenhouse on 7 Mar. 1984. Transplants were set in the field on $24 \mathrm{Apr}$. 1984 at the Vegetable Research Station, Bixby, Okla., and on 26 Apr. 1984 at the Plant Pathology Research Farm, Stillwater, Okla. The soil at Bixby was a Severn very fine sandy loam [coarse-silty, mixed (calcareous), thermic Typic Udifluvent]. The soil at Stillwater was a Norge loam (fine-silty, mixed, thermic Udic Paleustoll). The experiment was repeated in 1985 at Bixby and at the Fruit Research Station, Perkins, Okla. The soil at Perkins was a Teller loam (fineloamy, mixed, thermic Udic Argiustoll). Seed was sown in the greenhouse on 8 Mar. 1985. Transplants were set in the field on 26 Apr. 1985 at Bixby and on 1 May 1985 at Perkins. Each field site had been prepared with a broadcast, preplant-incorporated application of $44 \mathrm{~N}-19 \mathrm{P}-36 \mathrm{~K}\left(\mathrm{~kg} \cdot \mathrm{ha}^{-1}\right)$ in both years. Plots were $8 \mathrm{~m}$ long at each site, with 0.1 $\mathrm{m}$ between plants within rows and $0.9 \mathrm{~m}$ between rows. Thus, there were $\approx 111,100$ plants/ha.

Weeds were controlled with a post-transplanting application of $N, N$-dimethyl $-\alpha$ phenylbenzeneacetamide (diphenamid) at 4.5 $\mathrm{kg} \cdot \mathrm{ha}^{-1}$ at Bixby and Perkins in 1984 and 1985 , respectively, and with the same material at $5.6 \mathrm{~kg} \cdot \mathrm{ha}^{-1}$ at Stillwater in 1984 . A preplant-incorporated application of 2,6dinitro- $N, N$-dipropyl-4-(trifluoromethyl)benzenamine (trifluralin) at $560 \mathrm{~g} \cdot \mathrm{ha}^{-1}$ was used for weed control at Bixby in 1985. The Perkins site also received a preplant fumigation using 285 liters of a mixture of $80 \%$ chlorinated $\mathrm{C}_{3}$ hydrocarbons and $20 \%$ methyl isothiocyanate per hectare to control nematodes and soil fungi. Sprinkler irrigation was provided, based on subjective soil observations at each site.

A 2-m section of each plot was used for a single, destructive harvest in September, October, or November in both years (Tables 1 and 2). Plants were cut by hand at soil level, counted, and placed in burlap sacks. All fruit on the ground in each 2-m section, including those abscising during harvest, also were collected and counted separately. Fruit were removed from the plants in the laboratory. Fruit that were orange, green, bleached, or excessively infested with fungi were classified as culls. Marketable fruit were divided into two categories: "wet red" (fully ripe but succulent) and "oxblood" (leathery, partially dried, deep-red fruit). Oxblood fruit are the most commercially desirable, since they require less artificial drying by the processor. Stems, leaves, and fruit were dried at $48 \mathrm{C}$ for at least 7 days and weighed.

Representative samples of marketable fruit were analyzed for extractable red pigment in 1985. Calyxes were removed from dried fruit, and fruit were ground in a Wiley mill to pass through a No. 40 U.S. standard testing sieve $(0.42 \mathrm{~mm})$. Acetone extracts were analyzed for absorbance at $460 \mathrm{~nm}$ using a spectrophotometer (Spectronic 20; Bausch and Lomb, Rochester, N.Y.) according to American Spice Trade Association (ASTA) method 20.0 (ASTA, 1968). Data from the Oct. 1985 harvest are not reported because the samples' 


\begin{tabular}{|c|c|c|c|c|c|c|c|}
\hline \multirow[b]{3}{*}{ Harvest date $^{y}$} & \multirow{2}{*}{\multicolumn{2}{|c|}{ Abscised fruit }} & \multirow{3}{*}{$\begin{array}{c}\text { Avg wt stems } \\
\quad+\text { leaves } \\
\text { (g/plant) }\end{array}$} & \multicolumn{4}{|c|}{ Harvested fruit (abscised excluded) } \\
\hline & & & & \multirow{2}{*}{$\begin{array}{l}\text { Total wt } \\
\left(\mathrm{Mg} \cdot \mathrm{ha}^{-1}\right)\end{array}$} & \multirow{2}{*}{$\begin{array}{c}\text { Marketable wt } \\
\left(\mathrm{Mg} \cdot \mathrm{ha}^{-1}\right)\end{array}$} & \multicolumn{2}{|c|}{ Percent by wt of total: } \\
\hline & $\left(\mathrm{Mg} \cdot \mathrm{ha}^{-1}\right)$ & $(\%)$ & & & & Marketable & Oxblood \\
\hline \multicolumn{8}{|c|}{ Bixby } \\
\hline 3 Oct. (162) & 0.57 & 60 & 21 & 3.3 & 2.5 & 75 & 69 \\
\hline 5 Nov. (195) & 0.75 & 12 & 16 & 2.9 & 2.2 & 76 & 60 \\
\hline 17 Dec. (237) & 0.87 & 26 & 14 & 2.3 & 1.6 & 72 & 72 \\
\hline Linear & & & ** & $* *$ & & NS & NS \\
\hline Quadratic & NS & $* *$ & NS & NS & NS & NS & \\
\hline \multicolumn{8}{|c|}{ Stillwater } \\
\hline & 0.40 & 44 & 33 & 3.2 & 1.7 & 55 & 39 \\
\hline 5 Oct. (162) & 0.31 & 11 & 41 & 3.9 & 2.4 & 63 & 32 \\
\hline 7 Nov. (195) & 0.66 & 18 & 35 & 2.7 & 1.5 & 57 & 33 \\
\hline Linear & $* *$ & $* *$ & NS & NS & NS & NS & NS \\
\hline Quadratic & $* *$ & $* *$ & $m$ & $* *$ & $*$ & * & NS \\
\hline
\end{tabular}

"Marketable fruit were defined as "wet red" (fully ripe but succulent) and "oxblood" (leathery, partially dried, deep-red fruit). Dry weights are reported.

'Values in parentheses are days after transplanting.

${ }_{\text {Ns }, *, *}^{*}$ Nonsignificant or significant at $P=0.05$ or 0.01 , respectively.

Table 2. Effects of harvest date on yield and quality of paprika pepper. $1985 .^{2}$

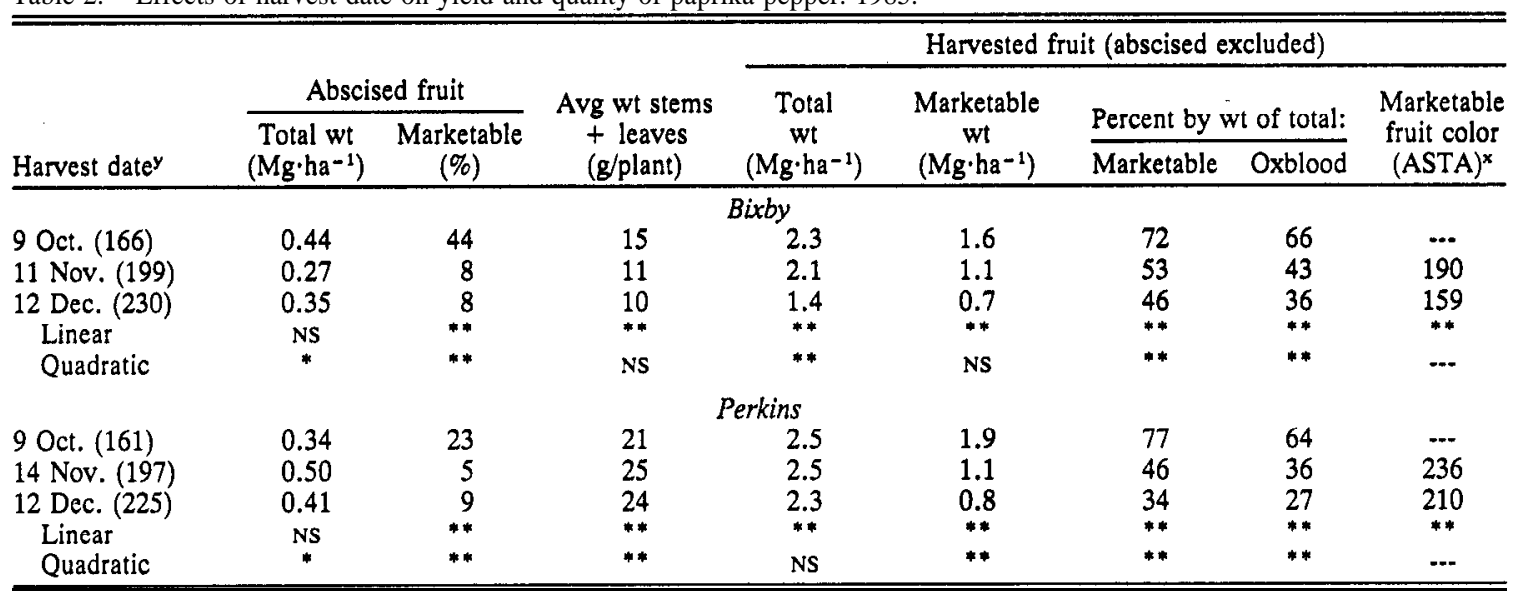

"Marketable fruit were defined as "wet red" (fully ripe but succulent) and "oxblood" (leathery, partially dried, deep-red fruit). Dry weights are reported.

${ }^{\mathrm{V}}$ Values in parentheses are days after transplanting.

xAmerican Spice Trade Association color units (ASTA, 1968); calyxes removed before analysis.

NS,*,**Nonsignificant or significant at $P=0.05$ or 0.01 , respectively.

color faded before extraction.

The design was a randomized block with eight replications per location. Analyses of variance were performed by location within each year due to frequent significant $(P<$ 0.05) location $\times$ harvest date interactions. Main effects of harvest date were partitioned into linear and quadratic components using single-degree-of-freedom contrasts.

There were no differences in plant stands among the plots in any of the experiments (data not presented).

Slight temperature differences between Bixby and Stillwater in 1984 had marked effects on plant growth. The microclimate of the Stillwater location apparently prevented damage from a light radiation frost (0C) on 30 Sept., while plants at Bixby suffered leaf burn and were $\approx 40 \%$ defoliated at the time of the first harvest ( 3 Oct.). Bixby plants continued to senesce after 3 Oct., but Stillwater plants were not killed until the first "hard" freeze of the year (-2C on 11 Nov.). Thus, total fruit abscission increased linearly over time at Bixby, while abscission was most pronounced at the December harvest date at
Stillwater (Table 1). Similarly, stem and leaf weights per plant and both total and marketable fruit yields decreased linearly over time at Bixby in 1984 but were highest at the November harvest date in Stillwater (Table 1). Marketable fruit as a percentage of total harvested fruit weight also was higher in November than at the other two harvest dates at Stillwater. This result is explained by a relatively high number of wet red fruit that ripened further following the October harvest date.

Frost effects were similar at the Bixby and Perkins locations in 1985. There were no frosts before the October harvest date and only light radiation frosts ( 0 to $-0.5 \mathrm{C})$ before the November harvest dates. The first "hard" freeze (-4C) occurred on 20 Nov. The different fruit abscission patterns at Bixby and Perkins (Table 2) are explained, in part, by strong rainstorms between 11 and 14 Nov., which increased fruit abscission at Perkins. Also, there was a general infestation of bacterial leaf spot [caused by Xanthomonas campestris pv. vesicatoria (Doidge) Dye] at Bixby, which led to reduced plant growth and lower yields compared to Perkins. The disease contributed to the linear decline in stem and leaf weights per plant over harvest dates at Bixby, while plants continued to grow between the October and November harvest dates at Perkins. Total and marketable fruit yields, however, declined linearly over time at both locations in 1985, with some differences in the rate of decline reflected in the significance of the quadratic response component (Table 2). The percentage of total harvested fruit weight for marketable and oxblood fruits decreased most markedly between the October and November harvest dates and more slowly thereafter at both locations. Also, marketable fruit red pigment intensity was higher in November than in December at both locations in 1985 (Table 2).

Palevitch et al. (1975) found no significant differences in dry red-fruit yield of paprika harvested from 157 to 178 days after direct seeding (DAS). Also, ASTA color intensity of fruits increased between the 167and 178-DAS harvests. However, the plants of Palevitch et al. (1975) had a shorter grow- 
ing season and were not subjected to frosts, unlike those in the present study.

This study generally supports work by Cotter and Dickerson (1984) in New Mexico. They found that yield of mature redChile fruit peaked in late October or early November and then declined through January. ASTA color over harvest dates varied between years in the study by Cotter and Dickerson (1984). However, in a later report from New Mexico, there was a significant linear loss of extractable red pigment as whole red-Chile fruit weathered naturally on the plants (Isidoro et al., 1990).

Total and marketable fruit yields were highest with October harvest dates in three of the four experiments in this study. There was a tendency for fruit abscission to increase as harvest was delayed, but usually $<20 \%$ of the abscised fruit were marketable after October (Tables 1 and 2). Plant growth continued beyond October in two of the four experiments, but this resulted in increased marketable yields only at Stillwater in Nov. 1984. Moreover, only $32 \%$ of the total harvested fruit yield from the Nov. 1984 Stillwater harvest was composed of partially dried oxblood fruit, an undesirably low percentage. Apparently, for crops established by transplanting, paprika harvest should be completed during October in the southwestern United States. Further research is needed to refine harvest dates and to correlate yield losses more closely with the occurrence of near-freezing and freezing air temperatures.

\section{Literature Cited}

American Spice Trade Association. 1968. Official analytical methods of the American Spice Trade Association. 2nd ed. Amer. Spice Trade Assn., Englewood Cliffs, N.J.

Cotter, D.J. and G.W. Dickerson. 1984. Delayed harvest reduces yield of dry red Chile in southern New Mexico. HortScience 19:692-694.
Isidoro, E., D.J. Cotter, and G.M. Southward. 1990. A comparison of color loss of red Chile pepper pods on or off the plant and during storage as powder. HortScience 25:954-955.

Kahn, B.A. 1985. Characterization of lodging differences in paprika pepper. HortScience 20:207209.

Marshall, D.E. 1984. Horticultural requirements for mechanical pepper harvesting, p. 389-396 In: American Society of Agricultural Engineers. Proc. Intl. Symp. on Fruit, Nut, and Vegetable Harvesting Mechanization, Bet Dagan, Israel, 5-12 Oct. 1983. Amer. Soc. Agr. Eng. Publ. 5-84.

Palevitch, D., S. Harel, J. Kanner, and I. BenGera. 1975. The effects of pre-harvest dehydration on the composition of once-over harvested sweet paprika. Scientia Hort. 3:143-148.

Wolf, I. and Y. Alper. 1984. Mechanization of paprika harvest, p. 265-275. In: American So\&y of Agricultural Engineers. Proc. Intl. Symp. on Fruit, Nut. and Vegetable Harvesting Mechanization, Bet Dagan: Israel, 5-12 Oct. 1983. Amer. Soc. Agr. Eng. Publ. 5-84. 